\title{
Motivations of Paying Zakat on Income: Evidence from Malaysia
}

\author{
Nur Barizah Abu Bakar (Corresponding author) \\ Department of Accounting \\ Faculty of Economics and Management Sciences \\ International Islamic University Malaysia \\ P.O. Box 10, 50728, Kuala Lumpur, Malaysia \\ Tel: 60-3-6196-4698 E-mail: nur.barizah@gmail.com \\ Hafiz Majdi Abdul Rashid \\ Department of Accounting \\ Faculty of Economics and Management Sciences \\ International Islamic University Malaysia
}

\begin{abstract}
Zakat on income is one of the emerging issues among Syariah scholars where they might have varying opinions regarding it. The aim of this paper is to identify factors that may influence the Muslims behaviour towards zakat on income. Academicians from three faculties in the International Islamic University Malaysia (IIUM) were used as sample in this study. They were sent self-developed questionnaires requiring them to indicate their level of agreement on certain factors which might influence them in paying zakat on income. Based on the mean ranking of those who pay zakat, the findings suggest that social, religious and economic factors prevail over the other relatively 'self-centered' factors. This study concludes by suggesting that there is a need for proper education on zakat which may eventually help the Ummah to benefit from the noble system of zakat.
\end{abstract}

Keywords: Zakat, Income, Malaysia, Factor, Determinant

\section{Introduction}

Zakat on income is an Islamic levy on personal income derived from sources or activities where labours are involved. It includes professional fees, labour compensation, salaries, wages, bonuses, grants, gifts, dividend income and the like (Nur Barizah, 2008a). It is one of the emerging issues in zakat. Various opinions are provided by jurists worldwide not only with regards to its zakatability, but also other areas related to it including its assessment, rate as well as deductions allowable, among others (Nur Barizah \& Abdul Rahim, 2007b). It follows that states in Malaysia also, due to Malaysian legal framework, has been practicing this zakat on income in numerous ways. There are not only different rulings among states, but also different extent of its enforcement and implementation. In essence, this diverse setting has led to zakat, and in this context, zakat on income becoming a relatively less-regulated institution at least in Malaysian environment (Muhammad Akhyar \& Nur Barizah, 2009).

This paper attempts to examine the views of academicians on the factors influencing their payment behaviour towards zakat on income. The important contribution of this paper is that those factors identified could be useful in planning or strategizing for the future of zakat system in the country.

This paper begins with the source of regulation of the zakatability of income. It then provides a brief discussion on the current practice of zakat on income in Malaysia. Then, it proceeds with a review of prior studies conducted related to zakat on income. The research question is then presented to frame the readers' mind in understanding the topic under study, followed by research methodology. Finally, it discusses the results of the study.

\section{Zakat on Income: Issues and Development}

The issue of zakatability of income has been a long debatable issue. Muslim scholars worldwide have various opposing opinions with regards to it (Nur Barizah, 2008a). Some scholars agree on its zakatability, others object, while the rest remain silent. This section will provide some insights on the arguments provided by these scholars.

Among the reasons given by those who believed in the zakatability of earned income are the following (Al Qardawi, 1973 in Kahf, 1999); (1) texts of zakatability are general and inclusive, (2) excluding this category of 
income is not consistent with levying zakat on agricultural income as well as on other kinds of zakatable incoe, (3) exempting this category results in relieving many of the rich persons while low income merchants and others are charged zakat, and, (4) charging this category zakat is consistent with the general priniciples of justice at large and its application to zakat is specific.

The evidence that earned income is zakatable are available from various sources of regulation, including Al-Quran, As-Sunnah and Qiyas. There are many Quranic verses which mentioned about the zakatability of income indirectly. The first evidence in the Quran which emphasis that income is one source of zakat item is in the second chapter (Al-Baqarah), verse 267:

"O ye who believe! Give of the good things which you have honorably earned and out of that which we bring forth for you from the earth of the fruits of the earth which we have produced for you". (Note 1)

This text of the zakatability of wealth is general and thus inclusive of many types of wealth, including income. We might conclude that Allah mentions that it is obligatory upon every Muslim to spend (pay zakat) on everything which he earned and therefore in this context those who earn income are subjected to zakat.

The second Quranic-based evidence on zakat on income comes from the same chapter, (Al-Baqarah), verse 141:

“.....and give its due on harvesting it".

Although this verse specifically refers to zakat on agriculture produce, it can also be applied to salaries and the like, since it does not explicitly exclude other types of earned income.

Besides those Quranic verses, the Prophetic tradition also have provided indirect evidence that income earned should be zakatable. Prophet complements the above Quranic verse in his sayings:

Narrated by Abu Burda:

"Every Muslim has to give in charity." The people asked, "O Allah's Prophet! If someone has nothing to give, what will he do?" He said, "He should work with his hands and benefit himself and also give in charity (from what he earns)."(Note 2)

From this Hadith, we can see that Prophet Muhammad indicated that one of the main purposed for securing a job in this world is to produce certain amount of income in order for Muslims to be able to perform his or her zakat obligation.

Nevertheless, despite the above evidences, there are a number of scholars who argued that income is not liable for zakat. Among them who supported this opinion are Imam Abu Hanifa, Imam Malik and Imam Syafie (Al-Qardawi, 1999). However, according to Al-Qardawi, who is one of the proponents of zakat on income, Muslims are not bound by any of these scholars' rulings. The argument provided by these scholars, among others, is that the Prophet never practiced nor charged zakat on income.

With regards to this issue, the proponents of zakat on income argued that fiqh on zakat is subjected to changes due to the rapid development of human's socio-economic environment (Nur Barizah, 2008b). Accordingly, through studying the modern conditions, Islamic jurists need to find the most appropriate rules that benefit the general public (maslahah 'ammah) as well as those that serving justice ('adl) as long as the derived rule does not contradict any Divine rule (Nur Barizah, 2007a).

In particular, zakatable items during the life of the Prophet PBUH (Note 3) are slightly changing from the zakatable items after the time of Prophet PBUH. It should be noted that at the time of the Prophet PBUH the people of Madinah used to hold wealth in the forms of livestock, gold and silver (whether used as money, jewellery or raw materials and final products of the jewellery industry), trade inventory and agricultural land (Muhammad Anwar, 1995). There was relatively very little investment in human capital which generates high labor income (Kahf, 1999, p.29). Similarly during the period of the first four successors (caliphs) of the Prophet $\mathrm{PBUH}$, there were no important changes in the pattern or structure of wealth and income although a tremendous increase in their quantity took place (Kahf, 1999).

However, later on, in the period of the following caliphs, there occur some structural changes in the forms of wealth and income, which consequently provide some precedent on the zakatability of income for the modern wealth. The first to take zakat on salaries was Caliph Muawiyah, during the Umayyah Caliphate (Nur Barizah, 2008b). Other includes Caliph Umar ibn Abdul Aziz, where he deducted the due zakat from the salaries of soldiers engaged by the State for defending boundaries. He also deducted the due zakat from periodical grants and prizes assigned to his citizens, whereby he deducted twenty-five out of each thousand (units of money) (i.e. $2.5 \%$ ), prior to handing them to the citizens. This, in the modern context, can be equated to the zakat payment 
through salary deduction. In essence, this means that both caliphs acted upon their individual point of view in this regard without the companies and righteous predecessors opposing them.

Looking at the history, it proves that the fiqh of zakat need to be reconsidered because of changing circumstances (Zarqa, 1984, in Kahf, 1999). At present, zakat on earned income is still considered as a contemporary issue and still debatable among Muslim scholars (Kamil, 2005). Despite the fact that there are an increasing number of its proponents, there are still some who strongly adhere to the traditional fiqhi view who believe otherwise. Kahf (1999) in expressing his concern on this issue commented that these scholars, who are the opponents of zakat on income, do not take the principle of justice into consideration. He argued that the majority of wealthy people in any contemporary Muslim society are virtually exempt from zakat while the poor agricultural population is charged at a greater rate. He boldly relates this scenario to the inherent flaws in today's Ijtihad and thus calls upon the role of specialized scholars in reconsidering this issue. It follows that zakat must be levied on salaries and professional income on the grounds that this satisfies the principle of justice in distributing the burden of supporting the poor among the rich regardless of the form their richness may take (Al-Qardawi, 1999; Kahf, 1999; Nur Barizah, 2008a).

\section{Zakat on Income in Malaysia}

In this paper, it is necessary to provide some insights on the current practice of zakat on income in the local context (i.e. Malaysia). Malaysia is a Muslim country comprising fourteen states. The administration of zakat in Malaysia is under the respective states jurisdiction, and not under the federal government (Nur Barizah, 2007a; Nur Barizah \& Abdul Rahim, 2007b). Thus, the law on Zakat is governed by each state's enactment, except for the states of Kedah, Sabah and Sarawak where it has its own zakat law (Mohd. Daud, 1998). At the national level, the National Fatwa Council has agreed, on 22 Jun 1997 that zakat on earned income is compulsory to be paid by those who are eligible to pay. While at the state level, many states in Peninsular Malaysia have issued fatwas that impose zakat on employment income as obligatory (Kamil, 2005). This would include Selangor, Wilayah Persekutuan and Melaka. In the case of Perak, they issued a contradict fatwa in the year 2004 (Hairunnizam et al, 2005), where it was enacted that zakat on income is not compulsory to be paid. Other states like Kedah, Perlis and Terengganu is yet to come out with any fatwa regarding zakat on income.

In the case of Selangor, where IIUM is located, it can be considered as the most advanced state in terms of its enforcement where the Selangor state government required all Muslim employees of the Federal government, statutory bodies, state government bodies, agencies and subsidiary companies serving at the state of Selangor to pay zakat on earning to Selangor Zakat Board (LZS) through salary deduction. This fatwa on the compulsion of zakat on income payment by Muslim individuals had been gazetted on $16^{\text {th }}$ January 2001 under the Islamic Legal Administration Enactment.

In spite of the enactments and fatwas which are in favour of zakat on income made by the respective authorities, as well as the legal applicability of these fatwas, zakat on income remains a voluntary practice rather than been highly compiled by Muslims in Malaysia. In essence, there is lack of enforcement at the state level which may impede the effectiveness of the laws and regulations. Further, the non-existence of established laws partly promotes increasing doubtfulness and uncertainties on the part of the Muslim community. By established law here, it means a law which is based on a unified opinion on the zakatability of income, plus, a law credible enough to be enforced by the respective authority.

In brief, from the preceding discussion, we can see that the zakatability of income is an ever contentious issue, in theory and practice alike. Hence, it is on this premise that this study is conducted in order to explore the reasoning behind the different belief and their behaviour thereon.

\section{Previous Studies of Zakat on Income}

The number of studies examining Muslims behaviour towards zakat on income has been increasing. Much of the research has examined the demographic influences towards Muslims behaviour in paying zakat on income (e.g. Mohd. Ali et al., 2003; Kamil, 2005; Hairunnizam et al., 2005; Nur Azura et al., 2005). Demographic factors which have been researched so far include gender, age, marital status, education level, number of dependants and income level. Most of these studies adopted multivariate logistic regression analysis in measuring the significance of the factors on their zakat on income behaviour.

For instance, Hairunnizam et al. (2005) tested thirteen factors that might influence the payment or non-payment of zakat on income in Malaysia. They distributed 2500 questionnaires to individual Muslims in every state in Malaysia, using random sampling method. By applying logistic regression analysis, they found that five factors significantly influence the payment of zakat on income in a positive direction. These factors include age, marital 
status, education level, income level and payment through salary deduction mechanism. Additionally, it is found that working female is more likely to pay zakat on income. Knowledge on Islam, awareness of income as 'ikhtilaf' wealth and satisfaction in zakat distribution are insignificant, though positively related.

Apart from that, there is a study done in testing the influence of the so-called intrinsic motivational factors of individual Muslim towards the compliance behaviour of zakat on employment income (e.g. Kamil, 2005). Among the intrinsic motivational factors included are perceived service quality, exposure on zakat promotional campaign, knowledge on zakat on income and religiosity. Kamil (2005) also take into account perception on zakat laws, perception on zakat enforcement, perception on fairness, and attitude. His study found that three variables, i.e. perceived service quality, level of zakat knowledge, level of exposure to zakat promotional campaign, to be significantly related to the compliance behaviour in a positive direction. The other variables i.e. religiosity was found to have a negative correlation with compliance behaviour.

In addition, there is also a study done which looks at the payment behaviour from the perspective of zakat collection. Nor Ghani et al. (2001), for example, tested whether factors like privatization of zakat institution, awareness regarding the zakat obligation, income growth and the rate of growth of zakat base population have any impact on zakat collection. They concluded that privatization has no significant impact on zakat collection, while the remaining three factors contributed to the differences in the zakat collection performance.

In the context of studies done on public institution of higher learning (IHLs), a fes studies analyzed the payment behaviour of employees in these institutions towards zakat on income (e.g. Mohd. Ali et al., 2003; Nur Azura et al. 2005). For instance, Mohd. Ali et al. (2003) surveyed 100 employees of National University of Malaysia (UKM). He found six factors may significantly influence their behaviour on zakat on income. These factors include gender, number of dependants, education level, knowledge on zakat on income, knowledge on Islam and level of piety (iman). However, factors like education level and knowledge on zakat on income negatively impact the zakat on income behaviour while the remaining factors are positively related. Nur Azura et al. (2005), on the other hand, surveyed 120 employees of Northern University of Malaysia (UUM).

In general, many of the previous studies tested the demographic factors which are anticipated as affecting the payment behaviour. They also tried to logically reason out and justify why the significant (and non-significant) factors act as they do. Very few of the previous studies tested the relationship between Muslim's perception and belief on certain zakat issues with their payment behaviour. The present study would complement the previous literatures by going a step further in identifying and emphasizing on the actual reasons for the payment behaviour, rather than analyzing the impact of demographic factors. In essence, it provides empirical evidence on the potential and actual reasons and causes for the payment behaviour.

\section{Research Question and Methodology}

\subsection{Research Question}

The unit which is appointed to collect zakat in the International Islamic University of Malaysia (IIUM) is the IIUM Endowment Fund Unit. The number of eligible tax payer in IIUM is 1179. Based on an estimation made by the Management Services Division (MSD) of IIUM in year 2005, should all tax payers pay zakat, the collectible amount of zakat would reach a total of RM2,063,586.90 per annum. This estimation is, however, has its limitation since the requirements in becoming a tax payer is not the same as the requirement to become eligible zakat payer. However, it still can serve as a basis in identifying the potentials of zakat on income particularly in IIUM. For the financial year-end 2005, only a total of 394 employees paid zakat with a total collection of RM448, 984.79 (refer to Table 1). In effect, only around 33 per cent (Note 4) of the potentially-eligible zakat payer in IIUM actually paid zakat, while in terms of collection amount, the actual collection is only around 22 per cent (Note 5) of the potential amount.

Based on the preceding, this study aims to identify the possible causes or reasons and deterrents which may influence the staff decision in whether to pay or not to pay zakat on income. This study can contribute in providing empirical evidence on the above issue. In particular, this paper is interested in getting answers to the following research question: "What are the underlying reasons behind the payment of zakat on income?"

\subsection{Research Methodology: Sample Selection and Research Instrumenmt}

The subjects are academicians from three faculties in IIUM. The main reason for choosing academicians is that most of them have reached an income level that can be subjected to zakat, setting aside other factors such as number of dependants and consequently total expenses. The faculties included in the study are Kulliyyah of Economics and Management Sciences (KENMS), Ahmad Ibrahim Kulliyyah of Laws (AIKOL) and Kulliyyah of Islamic Revealed Knowledge (KIRK). The basis for selecting academicians from these three faculties is that it 
is anticipated that the majority of them possess certain level of knowledge and understanding on zakat or its related area(s) in one way or the other. These knowledge and understanding might have been acquired through formal education, teaching and communication within the related areas of zakat.

A total of 281 self-developed questionnaires were distributed to all academicians from the three faculties through the personal assistants of the head of departments. There are different number of departments within each faculty, with three under both KENMS and AIKOL and four under KIRK. Accompanying each questionnaire was a cover letter briefly explaining the purpose of the survey.

The questionnaire is part of a larger survey examining the behaviour in the practice of zakat on income among academicians. In developing the questionnaire, we relied not only on previous studies but more extensively on our own experiences and observations. Our intention was not to identify all the possible behaviours researches could engage in, but to compile a set of issues or factors that the literature suggests exists and/or those we considered controversial as to their appropriateness.

The questionnaire comprises four sections. Section 1 contains demographic variables while Section 2 asks whether respondents pay zakat on income. Section 3 is regarding the reasons for paying or not paying zakat on income. Section 4 asks respondents the reasons for them choosing the different payment method, either through zakat centre or direct to the recipients. In this paper, we will not discuss Section 4 since it is beyond the scope of this paper.

Section 3 is divided into two; Section 3A and Section 3B. Section 3A is meant for those who pay zakat on income while those who do not pay are supposed to answer only Section 3B. In this paper, our focus will be only on Section 3A. In this section, respondents are presented with a 4-point Likert scale with 1 signifying 'strongly disagree', 2 'disagree', 3 'agree' and 4 'strongly agree'. A total of 9 reasons or motivations for paying zakat are presented. Respondents were asked to indicate their level of agreement to those reasons based on the given scale.

\section{Results, Discussions and Policy Implications}

\subsection{Demographic Data}

The number of response received from the 281 questionnaires sent is only 37 , which gives a response rate of a mere 13.2 per cent. Most respondents (64.9\%) aged between 31 and 40 years old, while $24.3 \%$ are between 41 and 50 years old (refer to Table 2). With regards to gender, majority of the respondent are female (59.5\%) (Refer to Table 3). Regarding the highest formal qualifications, $81.1 \%$ of respondents are PhD-holders, while $18.9 \%$ of respondents hold a Master degree (refer to Table 4).

It was also found that a very high majority of respondents (i.e. 97.3\%) do pay income tax. It shows that almost all of the respondents are in the higher income level, which will lead to a higher financial ability to pay zakat on earned income. However, when asked whether they pay zakat, a lesser percentage of respondents pay zakat on income (i.e. $83.7 \%$ ). At a glance, at this stage, we can say that zakat does not seem to be placed or perceived as a priority by a few of the respondents, as compared to taxation. Supposedly, being religious obligation, as well as the right of Allah, zakat should be performed foremost and prior to other tax payment. This result is among the observable impact of how the strict implementation of our conventional economic system has prevailed and dominated the Muslim's thoughts and practice as compared to the Islamic economics system. Apart from this, there are some other reasons identified on why some people do not pay zakat on income, however, it is beyond the scope of this paper to discuss on it.

\subsection{Factors Influencing the Payment of Zakat on Income}

With regards to the reasons or motivations for paying zakat, the result is arranged according to the means scores, from the highest mean to the lowest (refer to Table 5). Overall, the mean scores for all statements fall between the range of 3.68 and 3.90. This reflects that on average, respondents strongly agree with all the reasons stated. It can also be interpreted that these reasons strongly influenced them to pay zakat on income. Thus, in essence, all parties (e.g. zakat institutions, etc) who are committed in ensuring more eligible people perform their zakat on income obligation should take seriously these factors in developing both their short-term and long-term strategies in attracting more zakat (on income) payers.

Additionally, based on the highest mean scores, it appears that there are two primary reasons for the fulfillment of zakat on income obligation. Both achieved the same mean scores, first reason is that according to the respondents, zakat is part of their social obligation towards the Muslim Ummah (Statement 5) and the other reason is because they believe that in part of their wealth, there are rights of the poor and needy (Statement 4). These two statements or reasons are indeed inter-related (Naser et al., 2001). This finding reflects that most respondents understand the true conception of property and wealth in Islam, where man is a mere appointed 
agent or trustee of wealth and the ultimate Owner is Allah alone (Muhammad Akhyar \& Nur Barizah, 2009). Accordingly, the proprietor of wealth must always ready to spend in the way of God and to contribute to worthy causes. It makes him responsive to the needs of his society (Abdalati, 1994)

It is also interesting to note that the first four statements in the mean ranking are actually related to social (i.e. Statement 5 and 4), religious (i.e. Statement 1) and economic (i.e. Statement 8) motivations. (Note 6) With this spirits of paying zakat, it is understandable that the tax rebate given by government (i.e. Statement 3 ) and infrastructure provided (i.e. Statement 7), which can be regarded as relatively 'external' forces or motivations are not on top of the list of motivations to pay zakat. We find it quite satisfying that although tax rebate is allowed by government for those individuals who paid zakat, it does not seem to be the prime factor for people paying zakat on income. This proves that there are some people out there who do not rely on the incentive given by government to fulfill their religious obligation, which may partly reflects their strong and sincere commitment towards their religion.

Further, it is also found that the three least agreed factors are basically those factors under which we can categorized as 'uncertain/debatable or controversial issues' in zakat. This includes the zakatability of income (Statement 6), the eligibility of zakat payer (Statement 2) and the effectiveness of zakat distribution (Statement 9). These three factors are, indeed, among the widely debated issues in the area of zakat, both in terms of its fiqh and practice. Issues regarding the zakatability of income (Statement 6 ), for instance, have been discussed in reasonable length in the previous section. Debates on the eligibility in becoming zakat on income payer (i.e. Statement 2) on the other hand, revolves around the issue of assessment of zakatable amount and deductions that should be allowed in computing zakat payable. While the lack of agreement by respondents to Statement 9 shows that there is certain extent of lack of public confidence in zakat as an effective tool in wealth distribution.

In this respect, it is needed to be emphasized that zakat has been proven as a unique mechanism of wealth distribution in the history. Whenever Muslims truthfully applied the system of zakat as ordained by Allah and His messenger, the splendid objectives of zakat were fulfilled. Unfortunately, in the modern days, there occurs lack of public confidence in zakat contribution. This may be primarily due to the performance of the present zakat institution. Eventhough in several states we can see that high amount of zakat are collected, still, it is evident in the media that there are many people out there who are still suffer for lack of basic needs. This can be a point to ponder by those zakat administrators where their distributive function need to be further enhanced in terms of its effectiveness, transparency and accountability. This issue has been raised by Kahf (1999) pointed out that zakat must presumably be efficient and reasonably quick in eliminating poverty from Muslim societies since the main objective of zakat is the achievement of socioeconomic justice (Muhammad Akhyar \& Nur Barizah, 2009). He suggested that in order to speed up the process of the elimination of poverty, the state is called upon to find innovative forms of distribution of zakat fund with emphasis on the permanent rehabilitation of the poor and on providing permanent sources of income.

In Malaysia, among the suggestions made in order to improve the distribution function of zakat centre is that there should be a proper monitoring system on that function. The auditor report prepared by the Auditor General (National Audit Department, 2002; 281) for the state of Selangor raised the point that monitoring should not only be conducted on the collection function, but also on the distribution unit. This suggestion was highlighted when it was found that for the year 2002, the Selangor state's zakat centre conducted the monitoring task only on its collection function, but not on the other zakat arm i.e. distribution unit.

It is also need to be highlighted here that the result from this study, to a certain extent, supports the claim made by Hairunnizam et al. (2005) that Muslim public do not take into serious consideration the issue of zakat distribution since what matter more to them is that they would get tax rebate out of the zakat on income paid. This fact is evident from this study when the availability of tax rebate (i.e. Statement 3 ) is ranked higher in its influence towards the fulfillment of zakat obligation as compared to the effectiveness of zakat distribution (i.e. Statement 9).

\section{Conclusion}

Although the result of the survey shows an encouraging percentage of respondents do pay zakat on income, the fact still remains that only 33 per cent of those potentially-eligible zakat payer in IIUM actually pay zakat. This shows that there are still a lot more to be done by those involved in the collection of zakat, not only in IIUM, but throughout Malaysia. In fact, the scenario in IIUM can be considered as one of the benchmark to assess the potential of zakat on income elsewhere. This is mainly because IIUM is an 'Islamic' institution, which supposedly becomes the role model for other institutions, specifically on the issue of compliance to religious obligation. This study, in particular, found that internal factors still remains as important influences for the 
majority who pay zakat, as compared to the external factors. Overall, it implies that if proper education and knowledge is imparted to the Muslims, the zakat system in Malaysia can plan a far greater role in empowering the economics of the Ummah.

The findings of this survey may not be widely generalized due to at least three reasons. First, IIUM is a religious-based institution; hence its results might reflect only a section of the whole society. Second, the study included only three faculties within IIUM of which its members are anticipated to have some basic understanding on zakat or its related areas. Thus, the study is bias in its sample selection whereby it does not represent the real state of affairs in the society at large. Thirdly, the survey received a very low response, a mere $13.2 \%$, and thus limits its generalisability. Nevertheless, despite these limitations, the results of this study remain useful and indicative as they pinpointed certain essential issues which need to be considered by those who are involved in zakat to map their strategy towards enhancing the efficiency and effectiveness of the noble institution.

\section{References}

Abdalati, H. (1994). Islam in focus. Saudi Arabia: World Assembly of Muslim Youth. pp. 126-129.

Abdullah Y.A. (1989). The Holy Quran: Text, translation and commentary. USA: Amana Corporation.

Ahmad, Z. (1989). Public finance in Islam. International Monetary Fund Working Paper.

Al-Qardawi, Y. (1999). Fiqh az-zakat: A comparative study-The rules, regulations and philosophy of zakat in the light of the Qur'an and Sunna, trans. Monzer Kahf, edits. Abdalhaqq Bewley and Mohmed Isa Waly, London: Dar Al Taqwa Ltd.

Hairunnizam, W., Sanep, A. \& Mohd. Ali, M.N. (2005). Kesedaran Membayar Zakat Pendapatan di Malaysia. Islamic Economic and Finance Seminar, Universiti Utara Malaysia, 29-30 August, pp. 265-274.

Hannan, S.A. (undated). Zakat and the tax system. [Online] Available http://www.muslimtents.com/aminahsworld/Zakat and the taxsystem.html (October 9, 2005).

Kahf, M. (1991). Zakat: Unsolved issues in the contemporary fiqh. In Development and finance in Islam (edited by, Sadeq, Pramanik and Nik Hassan) Kuala Lumpur: IIU Press, pp. 173-190.

Kahf, M. (1999). The principle of socio-economic justice in the contemporary fiqh of zakat. The Iqtisad, University Islam Indonesia: CIESD.

Kamil Md. Idris. (2004). Kesan Persepsi Undang-undang dan Penguatkuasaan Zakat Terhadap Gelagat Kepatuhan Zakat Pendapatan Gaji. Prosiding Muzakarah Pakar Zakat, Universiti Kebangsaan Malaysia, pp. 201-212.

Kamil, M.I. (2005). The role of intrinsic motivational factors on compliance behaviour of zakat on employment income, in Isu-isu Kontemporari Zakat di Malaysia. (1st ed.). Melaka: UiTM pp. 137-170.

Mohd. Ali, M.N., Hairunnizam, W. \& Nor Ghani, M.N. (2003). Kesedaran membayar zakat pendapatan kakitangan professional: Kajian kes di UKM, in Prosiding Seminar Kebangsaan Dasar Awam Dalam Era Globalisasi: Penilaian Semula Ke Arah Pemantapan Strategi, Bangi, 16-17 September.

Mohd. Daud, B. (1998). The Malaysian zakat system: Law and policy reform. Seminar on Zakat and Taxation. Organized by International Islamic University Malaysia, 8-9 June.

Muhammad, A. (1995). Financing socio-economic development with zakat funds. Journal of Islamic Economics. Vol.4, No.1 \& 2, pp. 15-32.

Muhammad Akhyar, A. \& Nur Barizah, A.B. (2009). Accounting treatment for corporate zakat: A critical review. International Journal of Islamic and Middle Eastern Finance and Management, 2(1), 32-45.

National Audit Department. (2002). Auditor General's report: 2002. Selangor: NAD.

Nor Ghani, M.N., Mariani, M., Jaafar, A. \& Nahid, I. (2001). Can privatization improve performance? Evidence from zakat collection institutions. Islamic Economy Workshop. Faculty of Economics, UKM.

Nur Azura, S., Norazlina A.W. \& Nor Fadzlin, M.B. (2005). Gelagat Kepatuhan Pembayaran Zakat Pendapatan: Kajian Kes UUM. Seminar Ekonomi dan Kewangan Islam, Fakulti Ekonomi, Universiti Utara Malaysia, 29-30 August, pp. 275-296.

Nur Barizah, A.B. (2007a). A Zakat Accounting Standard (ZAS) for Malaysian companies. American Journal of Islamic Social Sciences, 24(4), 74-92. 
Nur Barizah, A.B. (2008a). Study guide: Zakat accounting concepts and applications. Kuala Lumpur: Wisewords Publishing.

Nur Barizah, A.B. (2008b). Zakat and taxation: A conceptual comparison. Journal of Islam and International Affairs, 2(3), 91-103.

Nur Barizah, A.B. \& Abdul Rahim, A.R. (2007b). Comparative study of zakah and modern taxation. Journal of King Abdul Aziz University: Islamic Economics, 20(1), 25-40.

\section{Notes}

Note 1. Translations of all Quranic verses in this article are based on Abdullah Yusuf Ali, The Holly Quran: Text, translation and commentary, Amana Corporation, Brentwood, Maryland, 1989.

Note 2. Extracted from Translation of Sahih Bukhari, Vol.2, Book 24, No. 524.

Note 3. PBUH refers to 'Peace Be upon Him'.

Note 4.The figure is calculated as 394 divided by 1179 .

Note 5 . The figure is calculated as $448,984.79$ divided by 2,063,586.90.

Note 6. A factor analysis has been performed on the various reasons motivating payment of zakat on income and three components have been extracted. These results are very much consistent with the above statement on the three main motivations influencing payment of zakat on income; i.e. social, religious and economic.

Table 1. Collection of zakat in year 2005 by IIUM

\begin{tabular}{|c|c|c|}
\hline Month & Collection (RM) & No. of payer \\
\hline January & $24,240.20$ & 193 \\
\hline February & $24,760.20$ & 198 \\
\hline March & $24,291.20$ & 195 \\
\hline April & $26,094.20$ & 216 \\
\hline May & $31,109.46$ & 274 \\
\hline June & $39,695.46$ & 333 \\
\hline July & $43,436.72$ & 363 \\
\hline August & $44,752.07$ & 379 \\
\hline September & $45,369.07$ & 382 \\
\hline October & $45,473.07$ & 385 \\
\hline November & $49,934.07$ & 395 \\
\hline December & $49,829.07$ & 394 \\
\hline TOTAL & $448,984.79$ & \\
\hline
\end{tabular}

Table 2. Distribution of respondents by age $(n=37)$

\begin{tabular}{|c|c|c|}
\hline Age & Frequency & Percent \\
\hline $21-30$ & 3 & 8.1 \\
\hline $31-40$ & 24 & 64.9 \\
\hline $41-50$ & 9 & 24.3 \\
\hline 51 and above & 1 & 2.7 \\
\hline
\end{tabular}

Table 3. Distribution of respondents by gender $(n=37)$

\begin{tabular}{|c|c|c|}
\hline Gender & Frequency & Percent \\
\hline Male & 15 & 40.5 \\
\hline Female & 22 & 59.5 \\
\hline
\end{tabular}

Table 4. Distribution of respondents by higher education obtained $(n=37)$

\begin{tabular}{|c|c|c|}
\hline Qualification & Frequency & Percent \\
\hline Masters & 7 & 18.9 \\
\hline Doctorate & 39 & 81.1 \\
\hline
\end{tabular}


Table 5. Motivations for paying zakat on income (According to Mean Ranking)

I pay Zakat on Income because:

\begin{tabular}{|c|c|c|c|c|c|c|}
\hline Statements & $\begin{array}{c}\text { Mea } \\
\text { n }\end{array}$ & $\mathbf{N}$ & $\begin{array}{l}\text { Strongly } \\
\text { Disagree }\end{array}$ & Disagree & Agree & Strongly Agree \\
\hline $\begin{array}{l}\text { STATEMENT 5: } \\
\text { I believe zakat is a social obligation towards the } \\
\text { Muslim Ummah }\end{array}$ & 3.90 & 31 & 0 & 0 & 3 & 28 \\
\hline & & & 0 & 0 & $9.7 \%$ & $90.3 \%$ \\
\hline $\begin{array}{l}\text { STATEMENT 4: } \\
\text { I believe that in part of my wealth, some of it is } \\
\text { the rights of the poor and needy. }\end{array}$ & 3.90 & 31 & 0 & 0 & 3 & 28 \\
\hline & & & 0 & 0 & $9.7 \%$ & $90.3 \%$ \\
\hline $\begin{array}{l}\text { STATEMENT 1: } \\
\text { I believe zakat on income is a religious } \\
\text { obligation }\end{array}$ & 3.84 & 31 & 0 & 1 & 3 & 27 \\
\hline & & & 0 & $3.2 \%$ & $9.7 \%$ & $87.1 \%$ \\
\hline $\begin{array}{l}\text { STATEMENT 8: } \\
\text { By paying zakat, I hope that the economics } \\
\text { condition of the Ummah will be improved }\end{array}$ & 3.84 & 31 & 0 & 0 & 5 & 26 \\
\hline & & & 0 & 0 & $16.1 \%$ & $83.9 \%$ \\
\hline $\begin{array}{l}\text { STATEMENT 3: } \\
\text { The government allows zakat paid to be } \\
\text { claimed as tax rebate }\end{array}$ & 3.81 & 31 & 0 & 0 & 6 & 25 \\
\hline & & & 0 & 0 & $19.4 \%$ & $80.6 \%$ \\
\hline $\begin{array}{l}\text { STATEMENT 7: } \\
\text { The facility is provided to pay zakat (e.g. salary } \\
\text { deduction, internet banking) }\end{array}$ & 3.81 & 31 & 0 & 1 & 4 & 26 \\
\hline & & & 0 & $3.2 \%$ & $12.9 \%$ & $83.9 \%$ \\
\hline $\begin{array}{l}\text { STATEMENT 6: } \\
\text { I believe that income should be subjected to } \\
\text { zakat }\end{array}$ & 3.77 & 31 & 1 & 0 & 4 & 26 \\
\hline & & & $3.2 \%$ & 0 & $12.9 \%$ & $83.9 \%$ \\
\hline $\begin{array}{l}\text { STATEMENT 2: } \\
\text { I am eligible to pay zakat on income }\end{array}$ & 3.77 & 31 & 0 & 0 & 7 & 24 \\
\hline & & & 0 & 0 & $22.6 \%$ & $77.4 \%$ \\
\hline $\begin{array}{l}\text { STATEMENT 9: } \\
\text { I believe that zakat is an effective mechanism } \\
\text { for wealth distribution }\end{array}$ & 3.68 & 31 & 1 & 0 & 7 & 23 \\
\hline & & & $3.2 \%$ & 0 & $22.6 \%$ & $74.2 \%$ \\
\hline
\end{tabular}

